Jelena Ž. Kostić ${ }^{1}$

UDC 316.356 .2

Institute of Comparative Law

004.738.5:316.472.4

Belgrade (Serbia)

342.721-053.2/.6

Original scientific paper

Accepted 15/11/2017

doi:10.5937/socpreg51-15397

\title{
POSTING CHILDREN'S' PHOTOGRAPHS ON SOCIAL NETWORKS: Sociological and legal aspects ${ }^{2}$
}

\begin{abstract}
Posting childrens' photographs on social networks can be an unsafe activity. Parents are free to choose whether to post photos of their children on-line or not. However, if it is done by a third person or an entity, the question of parental consent comes up to the surface. However, for those situations compulsory consent of both parents is not required by the national legislation in Serbia. Based on content analysis of relevant international documents and legislation, the author argues that in order to prevent potential abuses the already existing solutions need to be improved.
\end{abstract}

Keywords: parental consent, photographs, underage children, social networks.

\section{Introduction}

The rapid advancement of information technologies creates numerous positive possibilities, but also increases the possibility of violation of the right to privacy. Due to this technological progress, people can connect and communicate over long distances, in a relatively short period of time. Maintaining friendships and establishing business contacts is easier. That is why a large number of people use social networking services (Facebook, LinkedIn, Twitter, Instagram, etc.). A vast majority of users use Facebook, which had originated as a Harvard student's idea encapsulating online community of friends where photographs and profiles would be uploaded by users, that is, as an idea to create an interactive virtual community parallel to the social communities existing in the real world (Mezrih, 2010, p. 72). In this "interactive community", a large number of data, including photographs, have become available to the public. Consequently, a possibility to abuse these data has increased. ${ }^{3}$ Hence, a question often asked is how much the users of

1 suputjelena@yahoo.com.

2 This paper is a result of work on the project „Serbian and European Law - Compairson and Harmonization", funded by the Ministry of Education, Science and Technological Development, conducted at the Institute of Comparative Law; Project number: 179031.

${ }^{3}$ See https://www.vecernji.hr/techsci/policija-upozorava-prestanite-objavljivati-fotografije-djecena-facebooku-1065157 and https://www.fastcompany.com/3036073/the-creepiest-new-cornerof-instagram-role-playing-with-stolen-baby-photos, retrieved November 12, 2017. 
social networks are protected against misuses? In this regard, particularly serious problem is use of the networks by underage children (persons under eighteen years of age), or when on-line personal data such as photographs are posted by their parents.

Many companies like Facebook have their own policies, which the user is required to read and agree to before joining a social network. In this way, responsibility for posted content is transferred to the users, while registration with a social network represents a legal agreement. Thus, the majority of problems occurring on Facebook are related to the right to privacy, data protection, and the possibility of exercising the right to legal protection. These issues have been regulated by the European Union regulations, the most important being the Data Protection Directive (Directive 95/46/EC). ${ }^{4}$ It is considered to be the foundation for further development of European Union's legal framework regarding the right to privacy, protection of users' data, including users of Facebook and other social networking services, in electronic communication. Other directives have been passed only to enable further application of the Directive 95/46/EC in the area of electronic communications (Diligenski \& Prlja, 2014, pp. 7-6). Nevertheless, numerous cases of non-compliance with these regulations by Facebook have been reported in practice. Therefore, it appears that one needs to be very careful when it comes to the use of social networking services.

Regarding protection provided to children at both international and national level, there is a constant need to reassess effectiveness of the existing protection measures. Development of information technologies, especially a growing number of social networking services, has created new perils because even if an underage child does not own a profile on social networks, posting of a child's photograph on social networks can be done by someone else. Numerous tools, available even to a layman, allow for detection of the origin of photographs on the Internet. These tools make detection of a person's photo published on Facebook possible, but in addition also detection of the name of the place where it was taken. These tools allow for detection of photographs' origin on fake profiles and help prevent various abuses. However, at the same time they also may serve as tools various abuses. ${ }^{5}$

${ }^{4}$ Directive 95/46/EC of the European Parliament and of the Council of 24 October 1995 on the protection of individuals with regard to the processing of personal data and on the free movement of such data, Official Journal L. 281, 23/11/1995, Regulation (EU) 2016/679 of the European Parliament and of the Council of 27 April 2016 on the protection of natural persons with regard to the processing of personal data and on the free movement of such data, and repealing Directive 95/46/EC (General Data Protection), Official Journal of the European Union 119/2016. The document provides a better protection of personal data. According to Article 8, if a particular information on social services refers directly to a child, processing of personal data of the child is allowed only with a prior consent of the child's carer. EU member countries should make sure there are legal provisions in place making consent mandatory for individuals under the age of sixteen. Besides, member countries can even prescribe lower age, but not lower than thirteen, for mandatory consent as the legal limit. Article 40 of the Regulation foresees a need for a Code of conduct dependent on specific business practices of the legal entity processing personal data. Regulation from 2016 replaces the Directive from 1995. However, the regulation will be in force only from May 2018.

5 The following webpage post, http://www.istokpavlovic.com/blog/kako-da-otkrijete-poreklo-bilokoje-fotografije-na-internetu/, retrieved March 10, 2017, explains ways to detect name of a person whose photograph was posted on the Internet, as well as the place where the photograph was taken. However, one should have in mind that in this specific case, the instructions are aimed at users without high level of IT knowledge, and it is assumed that those with such knowledge would use some other tools in order to exploit personal data. 
Jelena Ž. Kostić, Posting children's' photographs on social networks: Sociological...

Public opinion with regard to publication of photographs of children on social networks is generally divided. In April 2017 an online survey has been conducted in the UK on a sample of one thousand adults. Based on results, $56 \%$ of respondents is against publication of photos of children, $70 \%$ think publishing photos of other people should not be done without permission, 36\% strongly believe access to personal photos should be restricted to friends or followers, and 50\% agree it is impossible to permanently erase images posted on the Internet (Kellon, 2017).

According to the international and national regulations, the rights and interests of underage children should be protected by their parents. When it comes to posting photographs of underage children on social networks, it seems that there are some legal gaps at the national level that need to be closed with an adequate provision in order to ensure the full protection of underage children when it comes to use of photographs on virtual social networks.

\section{Protection of the Children's Right to Privacy at the International Level}

According to the United Nations Convention on the Rights of the Child, a child is every human under the age of eighteen, unless otherwise stipulated by the applicable law, in which case adulthood would be attained earlier. ${ }^{6}$ By signing the Convention, countries have committed, through the national regulations, to make sure that no child is subjected to arbitrary or unlawful interference with his/her privacy, family, home or correspondence, nor to unlawful attacks on his/her honour and reputation. ${ }^{7}$ As long as the children are underage, their parents protect their rights and interests and are their legal representatives. According to the Convention, their common responsibility is the upbringing and development of the child and their primary concern is focused on the best interest of the child. In this regard, parents should take all the necessary measures to preserve these interests. According to the provisions of the Convention on the Rights of the Child, contracting parties are obliged to ensure that both parents have common responsibilities for the upbringing and development of the child. ${ }^{8}$ Even the universal instruments on human rights contain specific provisions for special protection of children (Dimitrijević et al, 2007, p. 221). Thus, the International Covenant on Civil and Political Rights envisages that every child, without any discrimination as to race, colour, sex, language, religion, national or social origin, property or birth, has the right, as a minor, to be protected by the family, society and the state it belongs to. ${ }^{9}$

The right to privacy has not been defined by the international documents. The European Commission of Human Rights has made an attempt to define the right to

6 Article 1 of the Convention on the Rights of the Child.

7 Article 16 of the Convention on the Rights of the Child.

8 Article 18 of the Convention on the Rights of the Child.

9 Article 24, paragraph 1 of the International Covenant on Civil and Political Rights. The International Covenant on Civil and Political Rights, signed on 19 December 1966 in New York, was ratified by the Law on Ratification of the International Covenant on Civil and Political Rights (“Official Gazette of SFRY” No. 7/71). 
private life. According to this definition, the right to private life implies that everyone has the right to choose a kind of life he/she prefers, protected from the public, which to an extent includes also the right to establish and maintain relationships with other human beings. ${ }^{10}$ The right to private life is constrained by the extent to which an individual exposes his/her private life, either through public contacts or in close connection with other protected interests. ${ }^{11}$ Nevertheless, children under certain age can hardly be expected to be aware of privacy concerns. Therefore, their parents are expected to care about their privacy in order to secure the best interests of the child. The same applies to posting child's photographs on the Internet via social networks.

The right to privacy is particularly vulnerable in the digital age. Based on Article 12 of the Universal Declaration of Human Rights, some later UN documents have highlighted the importance of protection of this right. Thus, the United Nations Resolution $68 / 167$ emphasizes that the rapid pace of technological development and the potential to use information technologies, and at the same time the possibility of personal data being used by companies and a large number of individuals, can contribute to violations of human rights, especially of the right to privacy. ${ }^{12}$ Therefore, the United Nations member states are urged to provide adequate protection of the right to privacy through their national legislation, not only through repressive measures (negative sanctions), but also through adequate preventive measures. The same is contained in the United Nations' Resolution No. 28/16 of 2015. ${ }^{13}$ It has been emphasized that an important goal of all countries is identification and clarification of the best principles, standards and practices for promotion and protection of the right to privacy, including establishment of special procedures. Therefore, equal protection of the right to privacy should be extended to violations on the Internet. However, the above-mentioned resolutions are joint conclusions, and as such only recommendations to the member states to provide the adequate protection at the national level for the benefit of humanity and the protection of human rights. Consequently, it is necessary to improve the national legislation in order to protect the right to privacy and, above all, the right to privacy of the child. Having in mind that underage children are passing through fundamental psychological and physical phases of development, hence being extremely sensitive, the focus should be on preventive measures.

\section{Protection of the Right to Privacy of the Child at the National Level}

When educational institutions post photographs of underage children, in practice they always ask for consent. The consent is usually given in writing using UNICEF's

10 The European Commission's report of 11 March 1979, paragraph 52 (cited according to V. Dimitrijević, M. Paunović, in collaboration with V. Đerić, 1998, p. 286).

${ }^{11}$ Ibid.

${ }^{12}$ Resolution 68/167 was adopted by the General Assembly on 18. December 2013, http://undocs. org/A/RES/68/167, retrieved March 10, 2017.

${ }^{13}$ Resolution 28/16 was adopted by the Human Rights Council on April 1, 2015, https://documentsdds-ny.un.org/doc/UNDOC/GEN/G15/068/78/PDF/G1506878.pdf?OpenElement, retrieved March 10, 2017. 
forms; however that format has not been officially regulated at the national level. Nevertheless, the form contains information about name and surname of the parent or guardian, his/her explicit consent for posting a photograph, as well as parent's ID number, address, and the date of consent. Written consent is given exclusively prior to posting the photograph. Anyhow, the fact that it is sufficient that only one parent consents before posting the photograph of the child, can pose a significant problem. It should be kept in mind that parents jointly exercise all parental rights as long as their marriage lasts. In addition, even after the divorce, consent of both parents is required with regard to certain rights which may affect the child's life. Thus, before posting photographs of the child on social networks by the school or any other natural or legal person, the consent of both parents should be sought, if possible. This would be in accordance with Article 18 of the Convention on the Rights of the Child, which stipulates that contracting parties are obliged to ensure recognition of the principle that both parents have common responsibilities for the upbringing and development of the child, and that their primary concern is the best interests of the child.

Obligation to obtain parental consent for posting photographs of their underage children on online social networking services is not explicitly provided for by any national regulation. In Serbia, the Law on Public Information and Media stipulates that information regarding private life or personal records (letter, diary, note, digital record, etc.), recording of images (photographs, drawings, film, video, digital, etc.) and audio recordings (taperecordings, gramophone records, digital, etc.), cannot be published without the consent of the person whose private life the information refers to, or of the person whose words, image or voice it contains, can lead to the recognition of that person's identity. ${ }^{14}$ Information and recording cannot be published without the consent of the person they refer to, if such publication can lead to violation of his/her right to privacy or some other right. Consent given to one publication, for a specific way of publishing, or to publication for a specific purpose, is not considered consent to repeated publication, to publication in a different manner or to publication for a different purpose. Nevertheless, the Law makes no mention of the explicit requirement to obtain parental consent prior to publishing photographs of the child on social networks. Article 81 of the Law provides for cases when some other person gives consent on behalf of a specific person for publishing his/her photograph in the media. This is in cases when a person whose photograph is published, is deceased. In this case, the consent is given by his/her spouse, his/her child having reached sixteen years of age, by his/her parent, brother, sister, by the legal person that the deceased was part of (an official body, member, employee) in the event the information or record refers to his/ her activities in that legal person, or by the person authorised by the deceased.

Taking into account all the above said, it seems that the legislator's intention was, above all, to protect the media outlets against unauthorized publication of personal data, as well as to protect the right to privacy of adults, while the right to privacy of the child remained unprotected. However, the right to privacy of the child can be observed as a part of the right to privacy of the child's parents. Pursuant to Article 12 of the Universal Declaration of Human Rights, no one can be subjected to arbitrary interference with his/ her privacy, family, home or correspondence, nor to attacks upon his/her honour and

${ }^{14}$ Article 80 of the Law on Public Information and Media ("Official Gazette of the Republic of Serbia", No. 83/2014, 58/2015 and 12/2016 - authentic interpretation). 
reputation. Thus, everyone has the right to legal protection in case his/her right to privacy has been violated. The obligation to respect the mentioned right is also provided for by Article 8 of the European convention of Human Rights as the obligation to respect his/ her private and family life, home and correspondence. A resolution of the Parliamentary Assembly of the European Council has determined that the right to privacy consists of the right to live one's own life with a minimum of interference, as well as of protection of family and home life, physiological and moral integrity, honour and reputation. It is not possible to list here all the rights that fall within the scope of the right to privacy, due to the mentioned right's natural connection to other individual and political rights, and because the scientific and technological development influence the need to protect new rights (Paunović et al, 2007, p. 216).

Based on the analysis of the existing national legislation, one can conclude that not even one provision provides for the mandatory written parental consent when the photographs of underage children are posted on social networks by natural persons, or by the other parent. If marital and family relations are undermined or the parents are divorced, the lack of such consent can be the cause for abuse of parental rights. Nevertheless, until the adoption of adequate regulations that will explicitly establish the obligation of obtaining such consent, one should take into account the provisions of other regulations, such as the Family Act of the Republic of Serbia. ${ }^{15}$

\section{Possible Solutions at the National Level}

The provisions of the Convention on the Rights of the Child have been implemented in legislations of the signatory states through national regulations. According to the Family Act of the Republic of Serbia, parents have the duty to exercise parental rights to the extent necessary for the protection of the personality, rights and interests of the child. If the parents are married, the mother and the father have joint parental rights. In case of divorce, the parent that does not exercise parental rights still has the right and duty to support the child, to maintain personal relations with the child, and to decide on issues that significantly influence child's life, jointly and consensually with the parent exercising the parental rights. The Law defines the issues that significantly influence the child's life. Accordingly, these include the following issues: the education of the child, larger medical interventions the child is subjected to, the change of the child's residence, and the disposal of the child's property of great value. In addition to the above-mentioned some other issues can also significantly affect the child's life. Bearing in mind the considerable vagueness regarding the disposal of photographs published on the Internet via social networking services (Facebook), one might ask to what extent this can affect the child's life in some future period. The earlier international documents were tailored for the Internet use of corresponding historical period. However, nowadays, when there is a large number of social networking services, problems occur in relation to their use by underage children, as well as to posting their photographs by legal or natural persons, including parents themselves. Children under a certain age still lack the ability to understand the meaning and significance of their actions, and therefore it is quite

15 The Family Act ("Official Gazette of the Republic of Serbia", No 18/2005, 72/2015-another law and 6/2015). 
reasonable to expect parents to play a very important role in guiding their children's psychological development.

When using social networks, underage children may be exposed to various forms of threats. Due to their insufficient psychological maturity, they are unable to correctly assess the severity of certain situations. Thus, in accordance with the Family Law, the rights of underage children are represented by their parents or legal guardians. Nevertheless, particularly dangerous is the situation when parents post photographs of their children on their profiles on social networking services. Since it is quite unclear how the photographs published on social networks are further handled, it can be concluded that there is a possibility that one of the parents may not consent to publishing of photographs of the underage child by the other parent. This issue could be solved by stipulating the provision of mandatory written consent by the other parent. Such practices should be encouraged especially in situations when after the divorce one parent independently exercises parental rights.

\section{Possible Abuses and Obligations of Facebook}

Photographs published on social networks can be misused, even after they have been deleted. A number of cases prove this. Some Facebook user with knowledge of URL address of a photograph can access it even after it has been deleted. It is possible to do this even several months after its deletion, by entering the URL address. In this way, some users gained access to the photographs that have been officially deleted three years earlier (Diligenski \& Prlja, 2014, p. 24). Deactivation of the profile is not permanent, but only temporary cancellation. Therefore, if a user deactivates his/her account, Facebook will keep the data in the storage in case the person returns back. This is contrary to the modern regulations on data protection. Data processing and usage represent the biggest dilemma. It is still unclear how Facebook deals with user data. All data on Facebook posted by users become Facebook's property (Ibid., pp. 119-120). Politics and law, by all accounts, are far behind the technology, and the basic founding principles of modern states are no longer able to follow the development of the Internet and information flow (Ibid., p. 120).

Although there are, at the EU level, documents regarding protection of personal data, current practice leads to a conclusion that social networking services do not comply with these regulations, but rather rely on their own rules and policies, and in some instances do not adhere even to them. For this reason, it seems that the only possible solution is the adjustment of national regulations to practical needs, i.e. stipulation of preventive mechanisms that will provide each individual with the opportunity to more adequately protect both individual's privacy and the privacy of person's underage child, whose rights and interests the person is obliged to protect in accordance with the Family Act.

As previously stated, the social networking services, primarily Facebook, establish their own rules of business, and consequently terms of service. When it comes to the photographs published on Facebook, this company is obliged to submit a copy of data categories upon user's demand. These data should also include data on face recognition, as well as other information that Facebook stores its database. The company can use user data to a limited extent for advertising, can use like button to a limited extent, must not track users based on likes, must not use user's pictures for advertising unless the user gives 
explicit consents, must provide the user with the option of deleting his/her pictures, the user must not be added into a certain group without his/her consent, inactive/deactivated profiles must be deleted if not used for a longer period of time, the last digit of an IP address must be deleted, entries related to search must be deleted after six months. Moreover, Facebook has to check the terms of data protection of the application owner, as well as to obtain yet another consent of the user, when the recognition option is illegally activated. ${ }^{16}$

\section{Use of Social Networks by Underage Children}

When it comes to the use of social networks by underage children, Facebook, as a social networking service with the largest number of users, does not keep track on how old is the person creating a user account. ${ }^{17}$ According to Facebook policies, a person must be at least thirteen years old at the time when the account is created. If a person is under thirteen years of age, status of a user of a social networking service is decided exclusively by his/her parents. They can report such circumstance by filling out the electronic form. Likewise, if a parent doesn't agree with it, he/she can delete his/her underage child's account even if the child is older than thirteen. ${ }^{18}$ In conclusion, the decision on whether the child will use Facebook or not depends exclusively on the decision of the child's parents. Although, even in this case both parents' opinions should be taken into account, and thus such decision should depend upon the will of both parents if possible. If one parent is deceased, is unknown, or for other reasons is unable to exercise parental rights, consent of only one parent should be sufficient. This would be in compliance with Article 18 of the Convention on the Rights of the Child according to which parents are obliged to jointly exercise parental rights and take measures in order to protect the best interests of the child. However, if the parents allow their underage child to use social networking service, the question arises whether it would be necessary, even in such situations, to take into account the attitude of both parents. If one takes into account the provisions of the Law on Public Information and Media, parental consent would be necessary in each specific case. This should be interpreted in the sense that if the parents permitted their underage child to open an account in accordance with terms of use of social networking service, they must give a separate written consent for publishing the child's photograph by other legal and natural persons. However, in this regard, the adequate protection of the best interests of the child would be questionable.

Caring about children and their upbringing inevitably requires from parents to, acting in child's best interest, impose various restrictions on their children. Assessment of the child's best interest is performed for each individual case. According to some opinions, it is better not to treat the child as an adult, while on the other hand some claim that such opinions are quite conservative and discriminatory towards children. In developed countries it is believed that when determining the best interests of the child, parents should be guided by the principles of individualism - principles of the protection of physical and psychological integrity of the individual, i.e. the child. In traditional communities,

${ }^{16}$ Europe versus Facebook, Nenigkeiten, http://www.europe-v-facebook.org/DE/de.html, (cited according to A. Diligenski, D. Prlja 2014, pp. 33-34).

${ }^{17}$ More about issues related to childrens' protection from electronic violence in N. Putnik., M., Milošević, V. Cvetković (2013).

${ }^{18}$ https://www.facebook.com/help/441374602560317/, retrieved March 10, 2017. 
priority is given to the values of the whole community, and the best interests of the child is considered to be acceptance of these values (Vučković, Šahović, 2000, pp. 98-103 cited according to V. Dimitrijević et al, 2007, p. 223).

Pursuant to the Family Act of the Republic of Serbia, majority is reached at the age of eighteen. It is also the moment when full legal capacity is reached. However, this legal status can also be obtained before reaching the age of eighteen. According to the provision of this Law, this happens in cases when an underage child concludes a marriage with the court permission before reaching the age of majority. ${ }^{19}$ Likewise, the court may also permit a minor to obtain full legal capacity if he/she has reached sixteen years of age, has become a parent and has reached the physical and psychological maturity to provide independently for his/her own personality, rights and interests. ${ }^{20}$ In these cases, parental consent for publishing photographs of underage children on social networks won't be required, because the person in case is considered capable of protecting his/her own personality, rights and interests by the court decision passed in extra-judicial proceedings.

\section{Conclusion}

The national regulations do not recognize the need to protect the right to privacy of the child in case of children's photographs being published on social networks by natural persons, including the other parent, if the parents are not married or are divorced. In the latter case, one may ask why the consent is required, since the parents, in accordance with the law, take measures to protect the rights and interests of the children. Still, such consent is necessary for several reasons. It is possible that one parent does not give consent to posting his/her underage child's photographs on social networking services. In addition, it is also possible that publishing of the child's photographs on social networking services could be used to undermine parental rights of one of the parents, by allegations of abuse.

Regarding the parental consent for posting the child's photographs on social networks by the school or sports clubs, the parental consent is generally sought up until the child's majority. When it comes to posting the child's photographs on social networks by legal persons (schools, sports clubs), it should perhaps be insisted on such a solution, while in other cases the upper age limit for obtaining the mandatory written consent should be sixteen years of age.

${ }^{19}$ Article 11, paragraph 2 of the Family Act.

${ }^{20}$ Article 11, paragraph 3 of the Family Act. 
Јелена Ж. Костић ${ }^{1}$

Институт за упоредно право

Београд (Србија)

\section{ОБЈАВЉИВАҢЕ ДЕЧИЈИХ ФОТОГРАФИЈА НА ДРУШТВЕНИМ МРЕЖАМА: Социолошко-правни аспекти ${ }^{2}$}

(Превод in extenso)

Сажетак: Објављивање фотографија деце путем друштвених мрежа може да представља опасну активност. Кад родитељи објављују фотографије своје деце, они су слободни у том избору. Међутим, уколико то врше друга лица, може се поставити питање постојања сагласности родитеља за њихово објављивање. Ниједан пропис на националном нивоу не предвиђа обавезну сагласност оба родитеља у таквим ситуацијама. На основу анализе садржаја релевантних међународних докумената и прописа, аутор настоји да укаже на потребу унапређења постојећих решења како би се спречиле потенцијалне злоупотребе.

Кључне речи: сагласност родитеља, фотографије, малолетна деца, друштвене мреже

\section{Увод}

Напредак информационих технологија је изузетно брз и ствара велике позитивне могућности, али и повећава могућност угрожавања права на приватност. Захваљујући њиховом напретку, омогућено је повезивање и комуникација људи на великим раздаљинама у релативно кратком року. То олакшава одржавање пријатељских веза, као и успостављање пословних контаката. Због тога данас велики број људи користи сервисе за друштвене мреже Фејсбук, Линкедин, Твитер, Инстаграм (Facebook, Linkeding, Twitter, Instagram) итд. Највећи број корисника користи Фејсбук; он је настао као идеја студената Харварда о онлајн заједници пријатеља са фотографијама и профилима које они сами постављају, односно као идеја о стварању интерактивне виртуелне заједнице паралелне са друштвеним заједницама које постоје у стварном свету (Mezrih, 2010, str. 72). У тој „Интерактивној заједници” јавности је постао до-

\footnotetext{
1 suputjelena@yahoo.com.

2 Рад је резултат рада на пројекту „Српско и европско право - упоређивање и усаглашавање”, који финансира Министарство просвете, науке и технолошког развоја, а спроводи се на Институту за упоредно право; број пројекта: 179031.
} 
ступан велики број података, а међу њима и велики број фотографија. Самим тим повећала се и могућност злоупотребе тих податка. ${ }^{3}$ Због тога се често поставља питање колико су корисници система за друштвене мреже заштићени од таквих злоупотреба. Нарочито велики проблем постоји када су у питању малолетна лица или кад личне податке, односно фотографије постављају њихови родитељи.

Велики број компанија, као што је Фејсбук, има сопствене политике које је корисник у обавези да прочита и да се с њима упозна пре самог приступања друштвеној мрежи. Стога се одговорност на тај начин пребацује на кориснике, а само приступање друштвеним мрежама представља неку врсту уговора по приступу. Тако је највећи број проблема на Фејсбуку везан за право приватности, заштиту података, као и могућност остваривања права на правну заштиту. Та питања су уређена прописима Европске уније од којих је најважнија Директива о заштити података (Директива 95/46/EC). ${ }^{4}$ Она се сматра основом за развој даљих правних прописа Европске уније у вези с правом приватности, као и заштитом података корисника електронских комуникација, а самим тим и корисника Фејсбука и других сервиса за друштвено умрежавање. Остале директиве су донете само како би се омогућила њена даља примена у области електронских комуникација (Diligenski i Prlja, 2014, cstr 6 и 7). Међутим, у пракси су забележени бројни случајеви непоштовања тих прописа од стране компаније Фејсбук. Због тога се чини да је потребно бити веома опрезан приликом коришћења сервиса за друштвене мреже.

Имајући у виду заштиту која се деци пружа како на међународном, тако и на националном нивоу, стално постоји потреба за испитивањем ефикасности постојећих мера заштите. Развој информационих технологија, а нарочито све већи број сервиса за друштвене мреже створио је и нове опасности. Уколико малолетно лице нема свој профил на друштвеним мрежама, проблем може да представља и објављивање његове фотографије на друштвеним мрежама. Многобројни алати омогућили су

\footnotetext{
${ }^{3}$ Види https://www.vecernji.hr/techsci/policija-upozorava-prestanite-objavljivati-fotografije-djecena-facebooku-1065157 и https://www.fastcompany.com/3036073/the-creepiest-new-corner-ofinstagramrole-playing-with-stolen-baby-photos 12.11.2017.

${ }^{4}$ Directive 95/46/EC of the European Parliament and of the Council of 24 October 1995 on the protection of individuals with regard to the processing of personal data and on the free movement of such data, Official Journal L. 281, 23/11/1995. Уредбом Европске уније број 679 из 2016. године (Regulation of the European Parliament and of the Council of 27. April 2016 on the protection of natural persons with regard to the processing of personal data and on the free movement of such data, and repealing Directive 95/47/EC) пружа се већа заштита приватности физичких лица. У складу са чланом 8. наведене Уредбе, уколико се одређена информација на друштвеним сервисима односи директно на дете, њихово коришћење је дозвољено једино уколико се претходно прибави сагласност лица које врши родитељско право. Земље чланице Европске уније треба да предвиде својим законодавством да је постојање такве сагласности неопходно уколико је реч о лицу које није навршило шеснаест година живота. Осим наведеног, земље чланице могу да предвиде и нижу старосну границу детета за добијање сагласности родитеља, али не испод тринаест година. У циљу спровођења Уредбе у члану 40. предвиђа се потреба доношења Кодекса понашања у зависности од специфичности пословања правног лица које обрађује податке о личности. Уредбом из 2016. године ставља се ван снаге Директива из 1995. године. Међутим, примена Уредбе почиње тек од маја месеца 2018. године.
} 
откривање порекла фотографије на интернету, чак и обличним лаицима. На тај начин могуће је открити фотографију неке особе која је објављена на Фејсбуку, али и место на којем је она настала. То омогућава нпр. откривање порекла фотографије на лажним профилима и доприноси спречавању различитих злоупотреба, али исто тако они могу послужити и као алати за извршење разних злоупотреба. ${ }^{5}$

Мишљење јавног мњења у погледу објављивања фотографија деце је углавном подељено. У Великој Британији је у априлу 2017. године спроведено онлајн истраживање у којем је учествовало 1000 одраслих особа. На основу резултата тог истраживања, 56\% испитаника није за објављивање фотографија деце путем друштвених мрежа, 70\% сматра да није у реду да се туђе фотографије објављују без сагласности, 36\% сматра да фотографије треба да буду доступне једино пријатељима или пратиоцима на друштвеним мрежама, а 50\% испитаника се слаже да је немогуће трајно избрисати фотографије које се објављују на интернету (Kellon, 2017).

Према међународним и националним прописима права и интересе малолетника требало би да штите њихови родитељи. Када је реч о правима и интересима малолетних лица на друштвеним мрежама, чини се да у неким ситуацијама на националном нивоу постоје правне празнине које је потребно попунити адекватном одредбом како би се обезбедила потпуна заштита малолетних лица у вези с коришћењем њихових фотографија на виртуелним друштвеним мрежама.

\section{Заштита права на приватност детета на међународном нивоу}

Према Конвенцији Уједињених нација о правима детета, дете је свако људско биће које није навршило осамнаест година живота, уколико се по закону који се примењује на дете пунолетство не стиче раније. ${ }^{6}$ Потписивањем наведене Конвенције, земље су се обавезале да ће националним прописима омогућити да ниједно дете не буде изложено произвољном или незаконитом мешању у његову приватност, породицу, дом или преписку, нити незаконитим нападима на његову част и углед. ${ }^{7}$ Док су деца малолетна, о њиховим правима и интересима старају се њихови родитељи, а они су и законски заступници свог детета. У складу с Конвенцијом, њихова заједничка одговорност је подизање и развој детета, а њихова основна брига старање о његовим најбољим интересима. У том смислу, родитељи би требало да предузму све потребне мере како би ти интереси били очувани. Према одредбама Конвенције о правима детета, стране уговорнице су у обавези да обезбеде да родитељи имају заједничку одговорност у подизању и развоју детета. ${ }^{8}$ Чак и универзални инструменти о људским правима садрже појединачне одредбе којима

${ }^{5}$ На веб-страници http://www.istokpavlovic.com/blog/kako-da-otkrijete-poreklo-bilo-koje-fotografijena-internetu/ објашњава се на који начин је могуће открити име особе чија је фотографија објављена на интернету, као и место на којем је настала одређена фотографија, 10.03.2017. Наравно, треба имати у виду да се у конкретном случају ради о упутствима за кориснике који не поседују висок ниво знања из области информационих технологија, па се претпоставља да они који имају таква знања могу да злоупотребе туђе податке коришћењем других алата.

6 Члан 1. Конвенције о правима детета.

7 Члан 16 Конвенције о правима детета.

8 Члан 18. Конвенције о правима детета. 
се предвиђа посебна заштита деце. (Dimitrijević et al 2007, str. 221) Тако је Повељом о грађанским и политичким правима предвиђено да свако дете, без икаквог разликовања заснованог на раси, боји, полу, језику, вероисповести, националном или социјалном пореклу, имовини или рођењу има право на мере заштите од стране његове породице, друштва и државе које захтева његов положај малолетника. ${ }^{9}$ Право на приватност није дефинисано међународним документима. Дефиницију права на приватни живот покушала је да дефинише Европска комисија за људска права. Према тој дефиницији, под њиме се подразумева право човека да живи како жели, заштићен од јавности, а до извесне мере обухвата и право на успостављање и неговање односа са другим људским бићима. ${ }^{10}$

Право на поштовање приватног живота ограничава се у мери у којој појединац сам доведе свој приватни живот у додир с јавним животом или у тесну везу са другим заштићеним интересима (Dimitrijević i Paunović, 1997, str. 286) Међутим, када су у питању малолетна лица, до одређеног животног доба тешко се може очекивати да су свесни своје приватности. Због тога се очекује да о њиховој приватности, а ради остваривања најбољих интереса детета, брину њихови родитељи. Тако је и у вези са објављивањем фотографија детета на интернету путем сервиса за друштвене мреже. Право на приватност је нарочито угрожено у дигитално доба. Полазећи од члана 12. Универзалне декларације о људским правима у неким каснијим документима Уједињених нација, указује се на значај заштите наведеног права. Тако се у Резолуцији Уједињених нација број 68/167 наглашава да нагли технолошки развој и могућност коришћења информационих технологија, а истовремено и могућност коришћења података о личности од стране компанија и великог броја појединаца могу да допринесу кршењу људских права, а нарочито права приватности. ${ }^{11}$ Због тога се земље чланице Уједињених нација позивају да својим националним законодавствима предвиде адекватну заштиту права приватности, и то не само предвиђањем репресивних (кривичних санкција), већ и предузимањем адекватних превентивних мера. Исти садржај има и Резолуција Уједињених нација број 28/16 из 2015. године. ${ }^{12}$ У њој се истиче да је битан циљ свих земаља идентификација и проналажење најбољих принципа, стандарда и праксе ради унапређења и заштите права на приватност, као и успостављање адекватних процедура. Због тога би једнака заштита праву на приватност требала да буде пружена и онда када је у питању његово угрожавање на интернету. Међутим, наведене резолуције представљају само заједничке закључке и позив земљама чланицама да ради добробити човечанства

9 Члан 24. став 1. Повеље о грађанским и политичким правима. Међународни пакт о грађанским и политичким правима који је потписан 19. децембра 1966. године у Њујорку ратификован је Законом о ратификацији Међународног пакта о грађанским и политичким правима („Službeni list SFRJ“, broj 7/71).

10 Извештај Европске комисије од 11. марта 1979. године, параграф 52 (нав. пр. V. Dimitrijević, M. Paunović u saradnji sa V. Đerić, 1998, str. 286).

${ }^{11}$ Resolution 68/167 has been adopted by the General Assembly on 18. December 2013, http://undocs.org/A/RES/68/167 10.03.2017.

12 Resolution 28/16 has been adopted by the Human Rights Council on 1 April 2015, https://documents-dds-ny.un.org/doc/UNDOC/GEN/G15/068/78/PDF/G1506878. pdf?OpenElement 10.03.2017. 
и заштите људских права обезбеде адекватну заштиту на националном нивоу. 3бог тога је ради заштите права приватности, а пре свега права приватности деце, неопходно унапредити национално законодавство. Имајући у виду чињеницу да се малолетници налазе у фази психофизичког развоја и да су у том периоду људска бића изузетно осетљива, тежиште би требало да буде на превентивним мерама.

\section{Заштита права приватности детета на националном нивоу}

Кад је у питању заштита права на приватност детета на националном нивоу, не постоје прописи којима је директно уређена његова заштита. Приликом објављивања фотографија деце на друштвеним мрежама од стране образовних установа у пракси се увек тражи сагласност. Она се углавном даје у писаној форми, на обрасцима UNICEF-a, али њихова форма није званично прописана националним законодавством. Тај образац садржи податке о имену и презимену родитеља или старатеља, његову изричиту сагласност за објављивање фотографије, као и број личне карте и адресу родитеља и датум давања сагласности. Писана сагласност се даје искључиво пре објављивања фотографије. Међутим, посебан проблем може представљати чињеница што је пре објављивања фотографије детета довољно да један од родитеља да своју сагласност. Ипак, требало би имати у виду чињеницу да родитељи заједнички врше сва родитељска права док траје брачна заједница. Осим тога, чак се и након развода мора тражити сагласност оба родитеља у погледу одређених права која могу имати утицај на живот детета. Због тога би пре објављивања фотографије детета путем друштвених мрежа, од стране школе или било ког другог физичког или правног лица, требало тражити сагласност оба родитеља уколико је то могуће. Такво поступање било би у складу са чланом 18. Конвенције о правима детета, а којом је прописано да су стране уговорнице у обавези да обезбеде признавање принципа да оба родитеља имају заједничку одговорност у подизању и развоју детета, док су најбољи интереси детета њихова основна брига.

Обавеза давања сагласности родитеља за објављивање фотографија њихове малолетне деце путем интернет сервиса за друштвене мреже није изричито предвиђена ниједним националним прописом. Законом о јавном информисању и медијима предвиђено је једино да се информација из приватног живота, односно лични запис (писмо, дневник, забелешка, дигитални запис и слично), запис лика (фотографски, цртани, филмски, видео, дигитални запис и слично), запис лика и запис гласа (магнетофонски, грамофонски, дигитални и слично), не може објавити без пристанка лица чијег се приватног живота информација тиче, односно лица чије речи, лик односно глас садржи, ако се при објављивању може закључити које је то лице. ${ }^{13}$

Информација и запис не могу да се објаве без пристанка онога на кога се односе, ако би објављивањем тога било повређено његово право на приватност или неко друго право. Пристанак дат за једно објављивање, за одређени начин објављивања, односно за објављивање у одређеном циљу не сматра се пристанком за објављивање на други начин, односно за објављивање у друге циљеве. Међутим, ни у једном случају у Закону се не спомиње изричита обавеза прибављања сагла-

13 Члан 80. Закона о јавном информисању и медијима („Službeni glasnik Republike Srbije”, broj $83 / 2014,58 / 2015$ и 12/2016 - autentično tumačenje). 
Јелена Ж. Костић, Објављивање дечијих фотографија на друштвеним мрежама...

сности родитеља пре објављивања фотографије детета на друштвеним мрежама. Чланом 81. Закона предвиђени су случајеви у којима сагласност уместо одређеног лица за објављивање његове фотографије путем средстава јавног информисања или других медија даје друго лице. То је нпр. ситуација када је лице чија се фотографија објављује преминуло. Тада пристанак даје његов супружник, дете од навршене шеснаесте године живота, родитељ, брат, сестра, правно лице чији је преминули био учесник (орган, члан, запослени) уколико се информација, односно запис односи на његово учешће у том правном лицу или лице које је умрли за то одредио.

Имајући у виду наведено, чини се да је интенција законодавца била пре свега да се заштите медијске куће и средства јавног информисања од неовлашћеног објављивања личних података, као и да се заштити право на приватност одраслих лица, док је право на приватност детета у том погледу остало незаштићено. Међутим, право на приватност детета може се посматрати и у оквиру права на приватност његових родитеља. Према члану 12. Универзалне декларације о људским правима, нико не може да буде субјект напада на његову приватност, породицу, дом или кореспонденцију, нити напада на част и репутацију. Стога свако има право на правну заштиту, уколико је повређено његово право на приватност. Обавеза поштовања наведеног права прописана је и чланом 8. Европске конвенције о људским правима као обавеза поштовања приватног и породичног живота, дома и преписке. Једном резолуцијом Парламентарне скупштине Савета Европе утврђено је да се право на приватност састоји како у праву да свако живи свој живот, с минимумом мешања, тако и у заштити породичног живота и дома, психичког и моралног интегритета, и части и угледа. Набрајање права која спадају у оквир права на приватност није могуће, како због природне повезаности наведеног права са другим индивидуалним и политичким правима, као и зато што научно-технолошки развој условљава потребу за заштитом нових права (Paunović i dr. 2007, str. 216).

На основу анализе постојећег националног законодавства може се закључити да ниједна одредба не прописује обавезну писану сагласност родитеља када се фотографије малолетне деце објављују на друштвеним мрежама од стране физичких лица, па и другог родитеља. Уколико су нарушени брачни и породични односи, или уколико је реч о деци разведених родитеља, недостатак такве сагласности може бити и повод за злоупотребу вршења родитељског права. Међутим, док се не донесу адекватни прописи којима ће на изричит начин бити прописана обавеза давања такве сагласности треба водити рачуна и о одредбама неких других прописа, као што је нпр. Породични закон Републике Србије. ${ }^{14}$

\section{Могућа решења на националном нивоу}

Одредбе Конвенције о правима детета имплементиране су у законодавство земаља потписница путем националних прописа. Према Породичном закону Републике Србије родитељи имају обавезу да врше родитељско право у мери која је неопходна за заштиту личности, права и интереса детета. Када родитељи живе у заједници, родитељско право припада и мајци и оцу. У случају развода брака,

${ }^{14}$ Породични закон („Službeni glasnik Republike Srbije”, broj 18/2005, 72/2015-dr. zakon и 6/2015). 
родитељ који не врши родитељско право има право и дужност да издржава дете, да са дететом одржава личне односе и да о питањима која битно утичу на живот детета одлучује заједнички и споразумно с родитељем који врши родитељско право. Законом је дефинисано која су то питања која битно утичу на живот детета. У складу с тим, то су следећа питања: образовање детета, предузимање већих медицинских захвата над дететом, промена пребивалишта детета и располагање имовином детета велике вредности. Осим наведених и нека друга питања могу такође битно да утичу на живот детета. Имајући у виду могућност злоупотребе фотографија које се објављују на интернету путем сервиса за друштвене мреже (нпр. Фејсбук), могло би се поставити питање у којој мери се то у неком наредном периоду може одразити на живот детета. Када су у питању међународна документа, она су прилагођења условима коришћења интернета у периоду кад су донета. Међутим, данас кад постоји велики број сервиса за друштвене мреже јављају се проблеми у вези с њиховим коришћењем од стране малолетних лица, као и објављивањем њихових фотографија од стране правних и физичких лица, па и самих родитеља. Деца до одређеног узраста не могу да схвате смисао и значај својих поступака, па се сасвим оправдано очекује да у том периоду родитељи имају важну улогу у усмеравању њиховог психолошког развоја.

Приликом коришћења друштвених мрежа, малолетна лица могу бити изложена различитим видовима опасности. Због недовољне психолошке зрелости, они нису у могућности да правилно процене озбиљност одрећене ситуације. Због тога, у складу са Породичним законом, права малолетних лица заступају њихови родитељи или законски старатељи. Међутим, посебну опасност представља ситуација када родитељи на својим профилима путем сервиса за друштвене мрежа објављују фотографије своје деце. Како је прилично нејасно на који начин се даље поступа са фотографијама које су објављене путем тих мрежа, може се закључити да је могуће да се један од родитеља не слаже са објављивањем фотографије малолетног детета од стране другог родитеља. То би се могло решити прописивањем обавезе давања писане сагласности од стране другог родитеља. Такву праксу би требало подстицати нарочито у ситуацијама када један од родитеља након развода брака самостално врши родитељско право.

\section{Могуће злоупотребе и обавезе Фејсбука}

Објављивање фотографија путем друштвених мрежа не представља сигуран начин да те фотографије неће бити злоупотребљене, чак и након њиховог брисања. O томе сведоче и примери из праксе. Сваки корисник Фејсбука који познаје URL адресу одређене слике може да јој приступи и након њеног брисања. То је могуће учинити и неколико месеци од брисања слике уношењем URL адресе. Неки корисници су на такав начин дошли и до фотографија, које су званично биле обрисане пре три године. (Diligenski i Prlja, 2014, str. 24). Због тога Фејсбук представља изузетно несигуран медиј за објављивање фотографија. Исто тако деактивација профила не значи његово трајно, већ само привремено укидање. Стога, уколико корисник деактивира свој налог, Фејсбук ће и даље држати његове податке, за случај да се врати. Управо такво поступање је супротно модерним прописима о заштити података. 
Јелена Ж. Костић, Објављивање дечијих фотографија на друштвеним мрежама...

Обрада и начин коришћења података корисника представља највећу недоумицу. Још увек није познато како Фејсбук поступа са подацима корисника. Сви подаци које корисници поставе на Фејсбук припадају и постају његово власништво. Уместо права појединца, они постају својина Фејсбука (Ibid. str.119 и 120).

Иако на нивоу Европске уније постоје докумената која се тичу заштите личних података, на основу примера из праксе закључује се да се сервиси за друштвене мреже не придржавају тих прописа у свом пословању, већ да примењују сопствена правила и политике, мада се у неким случајевима ни њих не придржавају. ${ }^{15}$ Због тога се као једино могуће решење намеће прилагођавање националних прописа потребама праксе, тј. предвиђање превентивних механизама који ће сваком појединцу дати могућност да што адекватније заштити како своју приватност, тако и приватност свога малолетног детета о чијим правима и интересима има обавезу да се стара у складу са Породичним законом.

Као што је већ наведено, сервиси за друштвене мреже, а пре свега Фејсбук своје пословање, а самим тим и начин његовог коришћења прописују сопственим правилима. Када су у питању фотографије које се објављују путем Фејсбука, наведена компанија има обавезу да достави копију категорија податка, коју захтевају корисници. Ти подаци треба да буду и подаци о препознавању лица, као и остали подаци које Фејсбук има у својој бази података. Наведена компанија податке корисника може ограничено употребљавати за рекламирање, може користити лајк (like) дугме у ограниченом обиму, не сме пратити кориснике на основу тог дугмета, слике корисника не сме користити за рекламе, осим уколико се корисник са тим изричито сагласио, кориснику мора да да могућност да обрише своје слике, корисник не сме да буде додат у одређену групу без своје сагласности, неактивни или деактивирани профили морају се обрисати уколико се не користе дуже време, мора да се обрише последњи број код IP адреса, уноси који су везани за претраживање морају да се обришу након шест месеци од датума уноса. Осим тога, Фејсбук мора да провери услове за заштиту података од стране власника апликације, као и да добије поновни пристанак корисника, када је опција препознавања илегално активирана. ${ }^{16}$

\section{Коришћење друштвених мрежа од стране малолетних лица}

Приликом коришћења сервиса за друштвене мреже од стране малолетних лица, Фејсбук, као сервис за друштвене мреже са највећим бројем корисника, не води рачуна о томе колико година има лице које отвара кориснички налог. ${ }^{17}$ Према политикама наведене компаније, лице које може да отвори сопствени налог, мора у тренутку његовог отварања да наврши најмање тринаест година живота. Уколико је реч о особи млађој од тог узраста, о томе да ли ће то лице бити корисник сервиса за друштвене мреже или не, одлучују искључиво његови родитељи. Они такву околност могу да пријаве Фејсбуку попуњавањем формулара у електронској

${ }^{15}$ Види стр. 3.

${ }^{16}$ Europe versus Facebook, Nenigkeiten, http://www.europe-v-facebook.org/DE/de.html. (нав. пр. A. Diligenski, D. Prlja, 2014, стр. 33-34).

17 О проблемима у вези са заштитом малолетних лица од електронског насиља види у: $\mathrm{N}$. Putnik, M. Milošević, V. Cvetković (2013, нав. пр. A. Diligenski, D. Prlja, 2014, стр. 33-34). 
форми. Исто тако, родитељ може да обрише налог свог малолетног детета које је навршило тринаест година живота у тренутку отварања властитог налог, уколико се са тим не слаже. ${ }^{18}$ Као што се може закључити, одлука о томе да ли ће дете користи Фејсбук налог или не, зависи искључиво од одлуке његових родитеља. Међутим, и у тим случајевима би требало водити рачуна о мишљењу оба родитеља, па би таква одлука требало да зависи од воље оба родитеља уколико за то постоји могућност. У случају да један родитељ није жив, да је непознат или да из других разлога није у могућности да врши родитељско право, требало би узети у обзир сагласност само једног од родитеља. Такво поступање било би у складу са чланом 18. Конвенције о правима детета према којој су родитељи у обавези да заједнички врше родитељско право и да преузимају мере у циљу заштите најбољих интереса свог детета. Међутим, уколико би родитељи дозволили малолетном детету да користи сервис за друштвене мреже, намеће се питање да ли би у таквим ситуацијама било неопходно узети у обзир став оба родитеља. Уколико би се узеле у обзир одредбе Закона о информисању и медијима, сагласност родитеља би била неопходна у сваком конкретном случају. То би требало тумачити на такав начин да уколико су родитељи дали сагласност малолетном детету да у складу с правилима о коришћењу сервиса за друштвене мреже отворе сопствене налоге, морају да дају посебну писану сагласност за објављивање фотографије детета од стране других правних и физичких лица. Међутим, у вези са тим могло би да се постави питање адекватне заштите најбољих интереса детета.

Старање о деци и њиховом подизању нужно захтева да родитељи намећу деци и различита ограничења, а у циљу остваривања најбољег интереса. Процењивање најбољег интереса детета врши се у сваком конкретном случају. Тако постоје ставови да је набоље за дете да се не третира као одрасло биће, док са друге стране постоје мишљења да је то врло конзервативно и дискриминаторски према деци. У развијеним земљама сматра се да се у утврђивању најбољег интереса детета треба руководити начелима индивидуализма, тј. заштите физичког и духовног интегритета појединца, тј. детета. У традиционалним заједницама, предност се даје вредностима читаве заједнице, а у најбољем интересу детета је да такве вредности прихвати (Vučković, Šahović, 2000, str. 98-103, цит. према Dimitrijević, 2007, str. 223).

Према Породичном закону Републике Србије, пунолетство се стиче са навршеном осамнаестом годином живота. Тада се стиче и потпуна пословна способност. Међутим, она се може стећи и пре навршене осамнаесте године живота. Према одредби наведеног Закона, то је случај уколико малолетно лице склопи брак пре пунолетства уз дозволу суда. ${ }^{19}$ Исто тако, суд може да дозволи стицање потпуне пословне способности малолетном лицу које је навршило шеснаест година живота, а које је постало родитељ и достигло телесну и душевну зрелост потребну за самостално старање о сопственој личности, правима и интересима. ${ }^{20}$ У тим случајевима неће бити неопходна сагласност родитеља за објављивање фотографија малолетног лица путем друштвених мрежа, јер ће се на основу судске одлуке донете у ванпар-

\footnotetext{
${ }^{18} \mathrm{https://www.facebook.com/help/441374602560317/} \mathrm{10.03.2017.}$

19 Члан 11. став 2. Породичног законика

20 Члан 11. став 3. Породичног законика.
} 
Јелена Ж. Костић, Објављивање дечијих фотографија на друштвеним мрежама...

ничном поступку сматрати да је реч о лицу које је способно да се самостално стара о својој личности, правима и интересима. Имајући у виду наведене одредбе, може се закључити да одређена малолетна лица са шеснаест година живота ипак стичу одређени ниво душевне зрелости неопходан за самостално старање о сопственој личности, правима и интересима. Због тога би у националним прописима требало заузети став да је сагласност родитеља за отварање сопственог Фејсбук налога малолетног детета неопходна до навршене шеснаесте године живота. Исти став би требало заузети и кад је у питању сагласност родитеља за објављивање фотографије детета од стране правних или других физичких лица укључујући и другог родитеља.

\section{Закључак}

Иако је потреба за заштитом права приватности када су у питању малолетна лица препозната од стране институција (школе, спортски клубови), она захтева и постојање адекватне законске заштите. Међутим, ни у националним прописима, а ни у пракси није препозната потреба да се право на приватност малолетних лица заштити и приликом објављивања фотографија малолетног лица од стране физичких лица, укључујући и другог родитеља уколико родитељи не живе у брачној заједници. У последњем случају могло би се поставити питање због чега је и тада неопходна сагласност, с обзиром на то да родитељи у складу са законом предузимају мере у циљу најбоље заштите права и интереса заједничке деце. Ипак, постојање такве сагласности неопходно је из неколико разлога. Могуће је да се један родитељ не слаже са тим да се фотографија његовог малолетног детета објављују путем сервиса за друштвене мреже. Осим тога, могуће је да објављивање фотографије детета путем сервиса за друштвене мреже буде искоришћено у циљу угрожавања вршења родитељског права једног од родитеља, позивањем на његову злоупотребу.

Када је у питању давање писане сагласности родитеља за објављивање фотографија путем друштвених мрежа од стране школе или спортских клубова у пракси се тражи сагласност родитеља све до пунолетства детета. Можда би када је у питању објављивање фотографија детета путем сервиса за друштвене мреже од стране правних лица (школа, спортских клубова) ипак требало инсистирати на таквом решењу, док би у осталим случајевима горња граница за постојање обавезне писане сагласности требало да постоји док дете не наврши шеснаест година живота. 


\section{REFERENCES / ЛИTEPATУPA}

Diligenski, A. and Prlja, D. (2014). Facebook and law, Beograd: Institut za uporedno pravo [In Serbian].

Dimitrijević, V. and Paunović, M. in collaboration with Đerić, V. (1998) Human rights, Beograd: "Međunarodna politika", "Službeni list SRJ”, Pravni fakultet, Fakultet političkih nauka [In Serbian].

Dimitrijević V., Popović D., Papić T. and Petrović V. (2007). International law of human rights, Beograd: Beogradski centrar za ljudska prava. [In Serbian].

Directive 95/46/EC of the European Parliament and of the Council of 24 October 1995 on the protection of individuals with regard to the processing of personal data and on the free movement of such data, Official Journal L. 281, 23/11/1995.

Kellon, L. (2017, August, 3), Posting children's photos on social media divides nation, http://www.bbc.com/news/technology-40804041 12.11.2017 12.11.2017.

Mezrih, B. (2010). The Accidental billionaires-The Founding of Facebook, A Tales of Sex, Money, Genius and Betrayal, Beograd: Evro-Giunti.

Paunović, M., Krivokapić, B., Krstić, I. (2007) The Principles of international human rights, Beograd: Megatrend univerzitet. [In Serbian].

Putnik N., Milošević M., Cvetković V., (2013), The problem of protecting educational institutions of cybercrime and electronic violence. Sociološki pregled, no. 1, Beograd, Srpsko sociološko društvo, 75-92. [In Serbian].

Regulation (EU) 2016/679 of the European Parliament and of the Council of 27. April 2016 on the protection of natural persons with regard to the processing of personal data and repealing Directive 95/46/EC, Official Journal of the European Union L 119/2016.

Resolution 68/167 was adopted by the General Assembly on 18. December 2013, available at: http://undocs.org/A/RES/68/167, accessed on 10/03/2017.

Resolution 28/16 was adopted by the Human Rights Council on 1 April 2015, available at: https://documents-dds-ny.un.org/doc/UNDOC/GEN/G15/068/78/PDF/G1506878. pdf?OpenElement, accessed on 10/03/2017.

The Convention on the Rights of the Child was adopted on 28 November 1989, at the 44th session of the United Nations General Assembly in New York; it was ratified by the Law on Ratification of the United Nations Convention on the Rights of the Child Official Gazette of SFRY - International Treaties No. 15/90, No. 4/96 and 2/97.

The Family Act Official Gazette of the Republic of Serbia, No 18/2005, 72/2015-another law and 6/2015 [In Serbian].

The International Covenant on Civil and Political Rights, signed on 19 December 1966 in New York, was ratified by the Law on Ratification of the International Covenant on Civil and Political Rights Official Gazette of SFRY No. 7/71 [In Serbian].

The Law on Public Information and Media Official Gazette of the Republic of Serbia, No. 83/2014, 58/2015 and 12/2016 - authentic interpretation [In Serbian]. 